\title{
REGULASI KONFLIK PEMILU (Studi Kasus Resolusi Konflik Pilkada 2015 dan Persiapan Pemilu 2019 di Kabupaten Sijunjung)
}

\section{Sri Anggraini ${ }^{1 *}$, Afrizal ${ }^{2}$, Indraddin ${ }^{3}$}

1. Graduate Program of Tata Kelola Pemilu, Faculty of Social and Political Science,Universitas Andalas, Padang, Indonesia.

$2{ }^{3}$ Department of Sociology, Faculty of Social and Political Science, Universitas Andalas, Padang, Indonesia.

\section{ARTICLE INFORMATION}

Submitted : 17 October 2019

Review : 03 November 2019

Accepted : 24 November 2019

\section{Available online: December 2019}

\section{KEYWORDS}

Election; Conflic; Resolution; Regulation

\section{CORRESPONDENCE}

*E-mail: iie.anggraini04@gmail.com

\section{A. PENDAHULUAN}

$\mathrm{P}$ emilu (Pemilihan Umum) dan Pilkada (Pemilihan Kepala Daerah) merupakan suatu proses atau sarana demokratis yang dilaksanakan dalam menyalurkan aspirasi dan keinginan rakyat, dimana rakyat diberikan kesempatan untuk memilih sesuai dengan hati nuraninya tanpa ada yang mempengaruhi atau mengintervensi sesuai dengan asas Pemilu yaitu langsung, umum, bebas, rahasia, jujur dan adil. Pemilu merupakan pemilihan yang dilakukan secara nasional yaitu untuk memilih presiden dan wakil presiden serta anggota legislatif, sedangkan Pilkada merupakan pemilihan yang dilakukan dalam konteks lokal dalam memilih kepala daerah baik itu gubernur, bupati ataupun walikota.

Penyelenggaran Pemilu atau Pilkada dilaksanakan oleh suatu lembaga yang independen. Menurut Surbakti dan Nugroho (2015:20) independen berarti adanya kebeba-

\begin{abstract}
A B S T R A C T
In the election, the conflict will always exist. Whether it is a conflict between the election participants, between the participants and the election organizers or among the election organizers itself. The purpose of this research is to analyze the contribution of the Election Conflict Regulation on handling the election conflict in Sijunjung Regency and to analyze the response of the conflicting parties to the usage of the Election Conflict Regulation in Sijunjung District. This research used a qualitative approach with a case study plan. To see this problem, the researcher used Ralf Dahrendorf's Conflict Theory of Regulation which explains that conflict regulation can affect the high and low escalation of conflicts that occurred. The results showed that in the resolution of conflicts that had occurred both in the 2015 Regional Heads Election conflict or the conflict during the preparation of the 2019 General Election, researcher found that the General Election Conflict Regulation played a role / contributed in resolving the conflicts, where the conflicts could be controlled and resolved properly without any increase in violence. This was proven by the conflicting parties that accepted the decision given by the authorities in its settlement plus there were no other conflicting actors involved in the conflict.
\end{abstract}

san bagi penyelenggara Pemilu dari intervensi dan pengaruh seseorang, kekuasaan pemerintah, partai politik dan pihak manapun dalam pengambilan keputusan.

Menurut UU Nomor 15 tahun 2011 tentang penyelenggara Pemilu, yang dimaksud penyelenggara Pemilu adalah Komisi Pemilihan Umum (KPU) sebagai pelaksana teknis, Badan Pengawas Pemilu (Bawaslu) sebagai badan yang mengawasi penyelenggaraan Pemilu pada setiap tahapan dan Dewan Kehormatan Penyelenggara Pemilu (DKPP) suatu lembaga yang tidak secara langsung terlibat dalam penyelenggaraan Pemilu, karena DKPP merupakan lembaga yang menindak penyelenggara Pemilu apabila terjadi pelanggaran kode etik.

Dalam menyelenggarakan Pemilu ada regulasi-regulasi atau aturan-aturan yang harus dipatuhi baik itu oleh penyelenggara Pemilu ataupun peserta Pemilu. Regulasi tersebut merupakan pedoman bagi penyelenggara 
Pemilu dalam melaksanakan atau menjalankan tugasnya. Selain itu dalam regulasi Pemilu juga terkandung regulasi konflik Pemilu yang menjadi pengendali apabila terjadi pertentangan baik itu antara sesama peserta Pemilu, antara sesama penyelenggara Pemilu ataupun antara peserta Pemilu dengan Penyelenggara Pemilu.

Menurut Surbakti dan Fitrianto (2015:77) hubungan antara kelembagaan KPU dan Bawaslu tidak dapat dipisahkan karena keduanya memiliki tugas dan kewenangan masing-masing yang saling melengkapi. Titik temu antara KPU dan Bawaslu adalah pada kepentingan bersama untuk saling melakukan koordinasi. Sedangkan dalam UU Nomor 15 tahun 2011 dinyatakan bahwa keberadaan KPU dan Bawaslu secara ideal berada dalam satu nafas harmonis sebagai penyelenggara Pemilu, maksudnya keberhasilan Pemilu tidak hanya ditentukan oleh kemampuan KPU dalam melaksanakan seluruh tahapan tapi juga oleh peran Bawaslu. Disini KPU sebagai pelaksana teknis setiap tahapan Pemilu dan Bawaslu pada fungsi pengawasan, penanganan pelanggaran dan penyelesaian sengketa Pemilu.

Keberadaan KPU dan Bawaslu sebagai satu kesatuan fungsi penyelenggaraan Pemilu dapat diartikan, bahwa keberhasilan penyelenggaraan Pemilu tidak saja akan ditentukan oleh kemampuan KPU dalam melaksanakan semua tahapan Pemilu tetapi juga oleh Bawaslu. Melalui tugas pengawasan dari Bawaslu, diharapkan Pemilu bisa terlaksana dengan baik dan sesuai dengan asasnya, yaitu langsung, umum, bebas, rahasia, serta jujur dan adil. Masing-masing tugas dan kewenangan yang dimiliki oleh kedua lembaga ini menunjukkan dua hal yang saling melengkapi dan saling menguatkan demi terselenggaranya Pemilu yang berkualitas.

Walaupun sudah ada aturan yang jelas mengatur bagaimana hubungan antara sesama penyelenggara Pemilu seperti KPU dan Bawaslu atau hubungan Penyelenggara Pemilu dengan peserta Pemilu (partai politik), namun fenomena yang ada sering terjadi pertikaian atau konflik dimana akhirnya berujung pada kekerasan dan tidak jarang menimbulkan korban.

Hal ini sesuai dengan yang diungkapkan dalam UNDP (2009) bahwasanya Pemilu memiliki peran ganda yaitu sebagai arena konflik dan sebagai instrumen resolusi konflik. Sebagai arena konflik adalah konsekuensi langsung dari ketegangan antar partai yang saling bertarung yang pada akhirnya mengarah pada kekerasan fisik ataupun non fisik, sedangkan sebagai instrumen resolusi konflik Pemilu dijadikan sebagai proses untuk mengakhiri konflik dengan menyerahkan keputusan ketangan rakyat. Senada dengan itu Ketua KPU Hasyim Asy'ari menyatakan, pada dasarnya Pemilu atau Pilkada adalah konflik karena didalamnya merupakan pertarungan memperebutkan kekuasaan dan konflik tidak dapat dihindarkan dalam pelaksanaan Pemilu atau Pilkada (Beritasatu.com).

Sebagaimana menurut Surbakti dalam Darmawan (2010:40) konflik merupakan "benturan" seperti perbedaan pendapat, persaingan, dan pertentangan antar individu dan individu, individu dan kelompok, kelompok dan individu atau kelompok dengan pemerintah. Senada dengan itu Pruit dan Rubin (2004:10) menyatakan kalau konflik merupakan perbedaan kepentingan atau suatu kepercayan bahwa aspirasi pihak-pihak yang berkonflik tidak dapat dicapai secara simultan.

Konflik yang terjadi didalam penyelenggaraan Pemilu atau Pilkada sangat menarik perhatian, dikarenakan konflik dapat mengganggu kinerja penyelenggara Pemilu dan mengganggu pelaksanaan tahapan Pemilu atau Pilkada. Konflik biasanya tidak hanya terjadi ditingkat pusat namun sampai kedaerah seperti kabupaten/kota. Konflik dapat terjadi antara sesama penyelenggara Pemilu, antara penyelenggara Pemilu dengan peserta Pemilu, antara sesama peserta Pemilu ataupun antara pendukung peserta Pemilu. Salah satu daerah yang didalam penyelenggaraan Pemilu atau Pilkadanya terjadi konflik adalah Kabupaten Sijunjung. Pada tahun 2015 Kabupaten Sijunjung melaksanakan Pilkada, dan dalam penyelenggaraan tersebut terjadi konflik yang berujung dengan dilaporkannya KPU Kabupaten Sijunjung oleh Panwaslu kepada DKPP dengan dugaan KPU melakukan pelanggaran kode etik penyelenggara Pemilu. Kemudian pada awal persiapan Pemilu 2019, terjadi lagi konflik antara KPU Kabupaten Sijunjung dengan Partai Politik yaitu PDIP dan juga berujung dengan dilaporkannya KPU ke Panwaslu karena diduga melakukan pelanggaran administrasi.

Kejadian yang terjadi di Kabupaten Sijunjung hampir sama dengan yang terjadi di daerah Sidoarjo, Menurut Purnamasari, Kahfi dan Rachman (2015:1-116) terkait dengan sudah jelasnya peran,tugas dan wewenang dari penyelenggara Pemilu seperti yang tertera di dalam UU Nomor 15 Tahun 2011, akan tetapi masih saja sering terjadi konflik selama proses penyelenggaraan Pemilu.

Secara umum konflik yang terjadi dikarenakan tidak adanya desain dan implementasi penyelenggara Pemilu, ketidakjelasan regulasi, tumpang tindih peranan dan 
interpretasi yang berbeda atas peraturan dan juga ketidakcakapan menangani perihal teknis Pemilu. Seharusnya dalam pelaksanaan Pemilu atau Pilkada semua pihak yang terlibat harus memahami regulasi atau aturan yang ada sehingga nantinya tidak ada pihak yang dirugikan dalam penyelenggaraan Pemilu atau Pilkada dan juga tidak akan menimbulkan konflik dalam penyelenggaraannya. Untuk lebih jelasnya dalam pelaksanaan Pemilu atau Pilkada ada beberapa sumber masalah yang menyebabkan terjadinya konflik menurut Badan Penelitian dan Pengembangan Kementerian dalam Negeri, diantaranya yaitu :

1. Independensi, netralitas dan Profesionalisme penyelenggara Pemilu. Hal ini berkaitan dengan kinerja DKPP, dimana DKPP telah memecat sebanyak 71 Anggota KPU dan Pengawas Pemilu dari berbagi daerah disebabkan karena tidak independen/netral. Indikasi ketidaknetralan KPU atau Pengawas Pemilu berkaitan dengan adanya relasi kepentingan partai politik, kekerabatan dan primordialisme.

2. Akurasi Data Pemilih Untuk Pemilu/ Pemilukada. Pada tahun 2009, permasalahan DPT menjadi bahan acuan, agar tidak terjadi pada pelaksanaan Pemilu/Pilkada berikutnya. Dimana pada penyelenggaraan Pemilu tahun 2009 tersebut diduga banyak terjadi kecurangan diantaranya pengelembu ngan suara sampai surat suara telah dicontreng terlebih dahulu. Akibat ketidakakuratan data pemilih tersebut sangat rawan menimbulkan konflik.

3. Pelanggaran pada tahapan Pemilu/Pilkada yang berpotensi terjadinya konflik.

a. Pencalonan. Ini disebabkan karena adanya ketidakpuasan dari calon atau pendukung calon ketika gugur dalam tahap pencalonan.

b. Pelanggaran Masa Kampanye. Pada masa kampanye beberapa pelanggaran yang berpotensi menyebabkan konflik adalah tindakan mencuri start, perilaku intimidatif dengan menunjukan kelemahan dan keburukan lawan, ketidaknetralan PNS dan pemanfaatan sumber daya daerah oleh incumbent terkait penggunaan anggaran, aparatur PNS dan dukungan tokoh-tokoh lokal.

c. Pelanggaran Pada Rekapitulasi Hasil Suara. Untuk di TPS kecurangan jarang terjadi, hal disebabkan karena banyak pihak baik itu saksi atau warga yang mengikuti jalannya penghitungan suara. Namun ditingkat kecamatan, kecurangan lebih sering terjadi dengan memindahkan suara dari calon satu ke calon yg lainnya.

d. Penetapan Pemenang. Konflik dapat terjadi apabila tidak ditetapkannya pemenang secara sah dan resmi oleh pihak yang berkompeten.

e. Dinasti Politik dan Cacat Demokrasi. Di Indonesia sering terjadi politik dinasti, dimana adanya hubungan kekerabatan antara kepala daerah dengan pejabat pemerintah. Pola lainnya adalah dengan maju pada waktu Pilkada dengan posisi yang berbeda, hal ini bertujuan agar dinasti politiknya bisa terbangun lebih besar.

f. Pengaruh primordialisme dan etnosnetrisme. Biasanya yang sering terjadi apabila ada calon atau kandidat yang kalah, untuk membuat kekisruhan disebarkan isu SARA untuk menjatuhkan pihak lawan.

Banyaknya anggapan yang menyatakan bahwa konflik dapat teratasi dengan sendirinya apabila dibiarkan merupakan anggapan yang salah, karena kenyataannya konflik akan terus berkembang dan akan semakin sulit dikelola apabila tidak cepat diselesaikan. Agar tidak terus berkembang maka diperlukanlah regulasi yang tepat dalam menangani konflik tersebut.. Dalam penelitian ini teori yang digunakan adalah teori regulasi konflik menurut Dahrendorf. Menurut Dahrendorf konflik merupakan sesuatu yang pasti terjadi dalam sebuah masyarakat karena adanya perbedaan kepentingan. Konflik timbul berawal dari orang-orang yang tinggal bersama dikarenakan adanya posisi-posisi para elit yang memliki kekuasaan untuk memerintah terhadap posisi lain yang menjadi sasaran perintah. Selain itu untuk menyelesaikan dan mengendalikan suatu konflik menurut Dahrendorf (1986:280) ada istilah regulasi konflik, yaitu merupakan bentuk-bentuk pengendalian pertentangan yang lebih menunjukkan dirinya sendiri kepada perwujudan pertentangan daripada sebab-sebabnya. Dahrendorf juga menyatakan, untuk efektifnya suatu regulasi ada tiga faktor yang mempengaruhinya yaitu pertama kedua kelompok yang bertentangan harus mengakui pentingnya dan nyatanya situasi pertentangan, kedua bagaimana kondisi kelompok-kelompok yang bertentangan (harus bersatu) dan ketiga kelompok yang bertentangan harus menyetujui aturan permainan formal tertentu.

Adapun bentuk-bentuk regulasi konflik yang dinyatakan oleh dahrendorf adalah konsiliasi, mediasi dan arbitrasi. Konsiliasi adalah pihak yang berkonflik berdiskusi secara terbuka dan mendalam untuk mencapai kesepakatan tanpa ada pihak yang memaksakan kehendak, disini ada pihak ketiga yang hanya memberikan pertimbangan-pertimbangan yang dianggap baik. Mediasi yaitu kesepakatan kedua belah pihak yang berkonflik untuk berkonsultasi dengan pihak luar yang diminta untuk 
memberikan nasehat, namun nasehat tersebut tidak mengikat. Arbitrasi yaitu kedua belah pihak sepakat untuk mendapatkan keputusan akhir yang bersifat legal dan ada pihak ketiga sebagai arbitrator.

Atas dasar uraian diatas, penulis tertarik untuk meneliti tentang regulasi konflik Pemilu ini. Disini peneliti berasumsi bahwa dengan adanya regulasi konflik Pemilu, konflik yang terjadi akan dapat diselesaikan dan konflik tidak akan mengarah ketingkat kekerasan. Permasalahan yang kemudian menarik untuk dibahas adalah apa kontribusi regulasi konflik Pemilu terhadap penanganan konflik Pemilu yang terjadi di Kabupaten Sijunjung. Disini konflik yang dimaksud adalah pertentangan yang terjadi antara KPU dan Panwaslu serta antara KPU dan PDIP. Dalam kaitan dengan rumusan diatas, tujuan yang ingin dicapai dalam penelitian ini adalah (1) untuk menganalisis kontribusi regulasi konflik Pemilu terhadap penanganan konflik Pemilu di Kabupaten Sijunjung. Ini dilihat dari segi pengaturan normatif penyelesaian konfliknya dan cara konflik tersebut diselesaikan. (2) untuk menganalisis respon para pihak yang terlibat konflik terhadap penanganan regulasi konflik Pemilu di Kabupaten Sijunjung, ini dilihat dari segi hasil peneyelesaian konflik dan respon atas hasil yang dikeluarkan dari penyelesaian konflik.

\section{B. METODE}

$\mathrm{P}$ endekatan yang digunakan dalam penelitian ini adalah pendekatan secara kualitatif dengan rancangan studi kasus. Dimana Menurut Ulfatin (2015:25) studi kasus merupakan suatu pendekatan dengan memusatkan perhatian pada suatu kasus secara intensif dan terinci dengan tujuan mempertahankan keutuhan objek yang diteliti. Penelitian ini bersifat deskriptif karena ingin menggambarkan dan memaparkan bagaimana proses terjadi konflik, penyelesaian konflik dan bagaimana regulasi konflik Pemilu berperan dalam penyelesaian konflik.

Agar tujuan dalam penelitian ini tercapai maka diperlukan data-data yang harus dikumpulkan berupa data primer dan data skunder. Data primer yaitu kata-kata dan tindakan yang diberikan oleh informan sedangkan data skunder berupa dokumendokumen seperti laporan-laporan yang mendukung data primer. Teknik pengumpulan data yang digunakan adalah wawancara mendalam dan pengumpulan dokumen. Adapun wawancara mendalam dilakukan dengan mencari informan-informan secara purposive sampling karena informan ini dianggap paham dan mengerti tentang isu dan permasalahan yang terjadi. Informan-informan yang digunakan dalam penelitian ini adalah komisioner KPU Kabupaten Sijunjung, komisioner Panwaslu Kabupaten Sijunjung, Pengurus Partai Politik dan TPD (Tim Pemeriksa Daerah) perwakilan dari DKPP.

Untuk menganalisis data ada tiga Teknik analisis data yang digunakan dalam penelitian ini yaitu pertama, reduksi data merupakan tahap menganalisis data dengan mengumpulkan data. Kedua, penyajian data yaitu menyajikan temuan penelitian dengan cara mengelompokkan datadata tersebut dan ketiga, menarik kesimpulan dari temuan yang dihasilkan tadi.

\section{HASIL DAN PEMBAHASAN}

\section{Konflik Pilkada 2015}

$\mathrm{P}$ ada waktu pelaksanaan Pilkada Tahun 2015, Kabupaten Sijunjung merupakan salah satu daerah yang ikut menyelenggarakan Pilkada. Dalam penyelengga raannya ada tiga pasangan calon bupati dan wakil bupati yang mendaftar ke Kantor Komisi Pemilihan Umum Kabupaten Sijunjung yaitu Drs. Muchlis Anwar. MSM - Maityetrinaldi. S.IP, Drs. H. Yuswir Arifin Dt. Indo Marajo - H. Arrival Boy dan Ashelfine. SH. MH - H.Alpian Kasir. Dalam penyelenggaraan Pilkada Kabupaten Sijunjung tahun 2015 tersebut, terdapat laporan salah cetak terhadap C1 KWK Plano Hologram, yang menyebabkan KPU Kabupaten Sijunjung dilaporkan ke DKPP oleh Panwaslu Kabupaten Sijunjung karena diduga melakukan pelanggaran kode etik penyelenggara Pemilu.

Berdasarkan wawancara yang peneliti lakukan dengan informan, konflik sepertinya telah terjadi sebelum adanya kejadian salah cetak C1 KWK Plano Hologram tersebut. KPU Kabupaten Sijunjung menyatakan bahwasanya laporan yang dibuat oleh Panwaslu ke DKPP terlalu mengada-ngada dan mendramatisir masalah. KPU menganggap jika Panwaslu mencari prestasi dari kasus yang terjadi, dimana Panwaslu bisa membuat masalah ini menjadi sesuatu yang besar karena disini tidak ada pihak yang merasa dirugikan atas kejadian salah cetak tersebut. Sedangkan Panwaslu Sijunjung berpendapat bahwasanya, laporan yang dibuat telah sesuai dengan prosedur dan aturan yang berlaku.

Dalam hal salah cetak C1 KWK Plano Hologram, KPU Kabupaten Sijunjung melakukan koordinasi dengan Kepolisian, Panwaslu dan Kesbang Pol Linmas. Koordinasi tersebut menghasilkan langkah-langkah yang dituangkan 
dalam Berita Acara untuk mengatasi supaya Pilkada dapat berjalan dengan lancar. Adapun langkah-langkah yang dilakukan telah disepakati atau disetujui oleh Panwaslu dan pihak terkait lainnya, sebagaimana yang dikemukakan oleh salah satu anggota Panwaslu Kabupaten Sijunjung Juni Wandri dalam wawancara yang dilakukan :

"Untuk persoalan kasus itu tidak ada tekanan. Kalau secara kelembagaan demi menyelamatkan pemilihan hari itu, tentu kami harus sepakat untuk mencarikan solusi atas kesalahan pencetakan C1 KWK Plano Hologram. Karena itu merupakan prasyarat awal untuk melakukan telly atau penghitungan suara. Ketika kita di Panwaslu tidak sepakat, berarti kita akan menghambat proses pelaksanaan Pilkada makanya kita harus sepakat".

Dengan adanya kejadian salah cetak tersebut KPU Kabupaten Sijunjung diduga oleh Panwaslu melakukan beberapa pelanggaran yang berkaitan dengan kode etik penyelenggara Pemilu. Dimana komisioner KPU diduga melanggar UU Nomor 15 tahun 2011 tentang penyelenggara Pemilu dimana KPU dianggap tidak adil, tidak profesional dan tidak efektifitas dalam mengadakan formulir C1 KWK Plano Hologram.

KPU diduga melanggar Peraturan Bersama KPU, Bawaslu dan DKPP, Nomor 13 tahun 2012, Nomor 11 tahun 2012 dan Nomor 1 tahun 2012 dimana KPU diduga kurang memelihara dan menjaga kehormatan lembaga dengan adanya kesalahan cetak tersebut dan juga sikap KPU dianggap tidak mengetahui aturan pengawasan dengan mengabaikan undangan klarifikasi yang dikirimkan oleh Panwaslu. KPU dianggap tidak ada memberikan perlakukan yang sama terhadap pasangan calon. Tidak menjelaskan kepada publik tentang kesalahan yang terjadi melalui pers.

Dari laporan yang diberikan oleh Panwaslu ke DKPP atas pelanggaran yang dilakukan oleh KPU. Dalam penyelesaiannya KPU dipanggil oleh DKPP untuk dimintai keterangan dengan menghadirkan saksi-saksi dan dengan berpedoman kepada regulasi yang ada yaitu Peraturan DKPP Nomor 1 tahun 2013 tentang pedoman beracara kode etik penyelenggara Pemilu dimana apabila terjadi pelanggaran kode etik, DKPP lah yang berhak untuk menindak. DKKP menuangkan Hasil tersebut dalam putusan DKPP RI Nomor : 11/DKPP-PKE-V/2016, dimana dari keputusan tersebut DKPP memberikan sanksi kepada empat orang anggota KPU berupa peringatan keras yaitu Taifiqurrahman (Ketua), Atika Triana (Divisi Logistik), Didi Cahyadi
Ningrat (Divisi Hukum) dan Ade Yulanda (Divisi Teknis). Sedangkan Lindo Karsyah (Divisi Sosialisasi) dan Irzal Zamzami (Sekretaris) diberikan sanksi berupa peringatan. Sesuai dengan wawancara yang dilakukan dengan Tim Pemeriksa Daerah (TPD) Sri Zul Chairiyah K :

"Sanksi yang diberikan terhadap Lindo Karsyah (Divisi Sosialisasi) dan Irzal Zamzami (Sekretaris) hanya peringatan dikarenakan hasil dari rekomendasi TPD. Karena TPD sangat tahu bagaimana hasil kerja KPU. Kalau DKPP kan hanya tentang aturan-aturan. Hal itu dilihat dari ada orang yang soft dan keras terhadap aturan. Mungkin dilihat Lindo Karsyah (Divisi Sosialisasi) dan Irzal Zamzami (sekretaris) selama ini bekerjanya selalu benar".

Atas keputusan tersebut KPU tidak bisa melakukan usaha banding untuk pembelaan diri, karena didalam aturan tidak ada yang mengatur tentang hal itu. Atas dasar itu juga KPU Kabupaten Sijunjung terpaksa menerima keputusan dari DKPP karena keputusan DKPP final dan mengikat, artinya keputusan DKPP tersebut merupakan keputusan akhir persidangan yang dilakukan. Sebagaimana yang dinyatakan oleh Ketua KPU Kabupaten Sijunjung melalui wawancara sebagai informan :
"Atas putusan DKPP itu, KPU tidak bisa melakukan apa-apa. Karena keputusan DKPP kan binding (final dan mengikat). Dalam celah hukumpun tidak ada lagi jalan, walaupun secara prosedur PTUN bisa memprosesnya. Namun bagaimana cara mengeksekusinya".

Berdasarkan wawancara tersebut, menurut KPU mereka tidak bisa melakukan usaha apapun, karena dalam hal ini keputusan DKPP final dan mengikat. Walaupun bisa dilakukan secara prosedur ke PTUN, namun yang mengeksekusi tetap KPU Provinsi. Setelah dijatuhkan putusan oleh DKPP, KPU Provinsi harus langsung mengeksekusi keputusan tersebut.

\section{Konflik Awal Persiapan Pemilu 2019}

$\mathrm{P}$ ada awal persiapan Pemilu 2019 terjadi juga konflik yang melibatkan KPU Kabupaten Sijunjung dengan Partai Politik yaitu PDIP. Dalam hal ini KPU dinyatakan oleh PDIP melakukan pelanggaran adminstrasi. Atas dasar itulah, PDIP melaporkan KPU Kabupaten Sijunjung ke Panwaslu dengan dugaan pelanggaraan administrasi. Permasala- 
han ini berawal pada waktu KPU Kabupaten Sijunjung melakukan verifikasi keanggotaan partai politik, dimana dalam pemenuham persyaratan dukungan keanggotaan, PDIP menyerahkan hanya sesuai batas minimal dari persyaratan yang disyaratkan undang-undang yaitu sebanyak 233 Kartu Tanda Anggota). Hal ini bisa mengakibatkan PDIP tidak lolos sebagai peserta Pemilu di Kabupaten Sijunjung, apabila ada salah satu dari anggotanya yang TMS (Tidak Memenuhi Syarat) dan ini diperkuat oleh pernyataan dari Ketua KPU Kabupaten Sijunjung.

Terbukti pada saat penelitian administrasi pertama ditemukan adanya dukungan keanggotaan PDIP yang TMS (Tidak Memenuhi Syarat). Setelah dilakukan penyerahan perbaikan oleh PDIP, ternyata ada empat nama yang teridentifikasi keanggotaan ganda oleh SIPOL. Selain itu pada waktu penelitian administrasi juga ditemukan satu nama yang tidak lolos disebabkan karena nomor KTA tidak sesuai dengan yang diinput dalam SIPOL. Pada waktu dilakukan verifikasi faktual kegandaan dilapangan, dua orang diantaranya menyatakan mendukung PDIP sedangkan dua orang lagi menyatakan tidak mendukung partai manapun.

Dalam melakukan verifikasi faktual, KPU Kabupaten Sijunjung menyatakan kalau pada waktu verifikasi faktual tersebut didampingi oleh staf Panwaslu. Namun dalam laporan yang diajukan oleh PDIP, menyatakan kalau dalam melakukan verifikasi faktual, KPU Kabupaten Sijunjung telah melakukan intimidasi terhadap anggotanya sehingga menimbulkan ketakutan kepada mereka, yang menyebabkan mereka membuat keputusan tidak memihak partai manapun. Berdasarkan permasalahan itulah, akhirnya PDIP melaporkan KPU Kabupaten Sijunjung ke Panwaslu Kabupaten Sijunjung. Dari laporan itu PDIP menduga kalau KPU melakukan pelanggaran terhadap regulasi Pemilu yaitu Peraturan KPU Nomor 11 tahun 2017 tentang Pendaftaran, Verifikasi, dan Penetapan Partai Politik Peserta Pemilu Anggota DPR, DPD dan DPRD.

Berdasarkan hal itu PDIP melaporkan KPU ke Panwaslu dengan tuduhan pelanggaran administrasi. Sesuai dengan yang terkandung dalam regulasi konflik Pemilu yaitu UU Nomor 7 Tahun 2017 tentang Pemilihan Umum dan Perbawaslu Nomor 2 tahun 2015 tentang Perubahan atas Peraturan Badan Pengawas Pemilu Nomor 11 tahun 2014, yang menyatakan bahwa Panwaslu adalah lembaga yang berhak menyelesaikan apabila terjadi pelanggaran adminitsrasi.
Dari uraian yang disampaikan oleh PDIP dan keterangan dari saksi-saksi, Panwaslu memutuskan kalau KPU Kabupaten Sijunjung tidak terbukti melakukan pelanggaran administrasi. Panwaslu menyimpulkan berdasarkan jawaban yang sudah disampaikan baik oleh saksi dari PDIP ataupun dari KPU Kabupaten Sijunjung, menegaskan dan menyimpulkan bahwa proses verifikasi yang dilakukan oleh KPU Sijunjung sudah memenuhi peraturan perundangundangan dan ketentuan yang berlaku, serta tidak terbukti secara materil substantif melakukan pelanggaran administratif seperti yang dituduhkan oleh pelapor. Disini Panwaslu bertindak sebagai arbitrator atas kasus yang terjadi antara KPU dan PDIP.

Atas keputusan yang dikeluarkan oleh Panwaslu, PDIP yang merasa sebagai pihak yang dirugikan berusaha melakukan usaha banding dengan mengirimkan laporan koreksi ke Bawaslu RI, namun hal itu tidak jadi terlaksana karena sesuai dengan aturan yang berlaku laporan yang dikirmkan tersebut sudah harus sampai tiga hari sesudah keputusan dikeluarkan. Atas dasar itu PDIP akhirnya menerima keputusan yang dikeluarkan oleh Panwaslu. Hal ini diperkuat dengan pernyataan dari anggota Panwaslu Juni Wandri :

"Sampai sekarang tidak ada tanggapan dari PDIP, berarti tidak ada masalah bagi PDIP. PDIP menganggap itu tidak jadi masalah disebabkan karena ada perubahan SE (Surat Edaran) untuk memverifikasi ulang semua partai termasuk partai lama. Sehingga hasil dari verifikasi tersebut di tingkat nasional PDIP lolos, makanya PDIP tidak mempermasalahkan ini lagi."

Dari hasil penelitian yang dilakukan ditemukan bahwa, dari kedua konflik yang terjadi konflik dapat diselesaikan dengan baik dengan berpedoman kepada regulasi Pemilu dan regulasi konflik Pemilu yang ada. Dengan adanya regulasi konflik Pemilu, konflik yang terjadi dapat dikontrol dan diselesaikan dengan baik sehingga konflik tidak berkembang kearah yang lebih tinggi. Selain itu dengan adanya regulasi konflik Pemilu, konflik yang terjadi tidak memunculkan aktor-aktor konflik yang baru yang nantinya dapat menyebabkan konflik menjadi berkembang kearah yang lebih tinggi atau kearah kekerasan.

Sesuai dengan teori Dahrendorf, konflik dapat diselesaikan dengan adanya regulasi konflik. Dalam penyelesaian konflik semua pihak yang terlibat dapat menerima hasil keputusan keputusan yang dikeluarkan oleh pihak yang berwenang seperti DKPP dan Panwaslu. 
Pada kedua kasus konflik yang terjadi, regulasi konflik Pemilu yang digunakan adalah berbentuk arbitrasi, dimana penyelesaian dengan menggunakan bantuan lembaga peradilan yang nantinya menghasilkan keputusan secara legal dan wajib dipatuhi karena bersifat final dan mengikat. Menurut Dahrendorf dalam menggunakan regulasi baik itu regulasi Pemilu ataupun regulasi konflik Pemilu, regulasi ini bisa efektif apabila :

1. Kedua belah pihak mengakui kenyataan dan situasi konflik yang terjadi antara mereka. Baik konflik yang terjadi pada waktu Pilkada tahun 2015 antara KPU dan Panwaslu atau Persiapan Pemilu tahun 2019 antara KPU dengan PDIP, mereka sama-sama menyadari bahwa ada sesuatu yang terjadi diantara mereka dimana KPU menyatakan kalau Panwaslu terlalu mengada-ngada dan mendramatisir laporan yang diajukan ke DKPP atas dugaan pelanggaran kode etik, sedangkan Panwaslu merasa kalau adanya temuan tentang salah cetak C1 KWK Plano Hologram tersebut menunjukkan kalau KPU tidak profesional, tidak cermat dan tidak teliti dalam melakukan pekerjaan dalam pengadaan logistik Pemilu sehingga KPU harus dilaporkan ke DKPP sebagai lembaga yang berwenang untuk mengadili penyelenggara Pemilu yang melakukan pelanggaran kode etik. Sedangkan untuk kasus antara KPU dan PDIP, KPU merasa tidak melakukan pelanggaran administrasi yang dituduhkan oleh PDIP karena KPU bertindak dalam melakukan pekerjaannya sesuai dengan aturan yang berlaku tentang verifikasi faktual kegandaan. Namun PDIP merasa kalau KPU telah melakukan intimidasi dan tekanan terhadap anggotanya yang mengakibatkan anggotanya menyatakan tidak memilih partai manapun dan hal ini menyebabkan PDIP tidak lolos untuk menjadi peserta Pemilu 2019 dan hal ini berujung dengan dilaporkannya KPU ke Panwaslu.

2. Kepentingan-kepentingan yang diperjuangkan harus terorganisasi secara rapi, tidak tercerai berai dan tidak terkotak-kotak sehingga masing-masing pihak memahami dengan jelas lingkup tuntutan pihak lain. Dalam memperjuangkan suatu masalah yang berujung pada konflik, kedua belah pihak yang berkonflik harus memahami bahwa dari konflik yang terjadi ada kepentingankepentingan atau tujuan-tujuan yang sedang diperjuangkan.

3. Kedua belah pihak menyepakati aturan main yang menjadi landasan dan pegangan dalam hubungan dan interaksi di antara mereka. Dalam hal ini Panwaslu dan PDIP sebagai pihak yang melaporkan KPU, secara jelas dan rinci menguraikan atas dugaan pelanggaran yang dilakukan oleh KPU. Aturan-aturan dan Pasal-Pasal mana yang dilanggar dengan jelas diuraikan dalam laporannya. Kemana KPU dilaporkan, bagaimana penyelesainnya dan apa sanksinya. Dari uraian tersebut dapat dilihat kalau dengan adanya regulasi konflik Pemilu dapat meredam konflik yang terjadi.

\section{KESIMPULAN}

$\mathrm{P}$ emilu merupakan wujud demokrasi yang memberikan ruang untuk kompetisi damai yang mengandung gagasan-gagasan politik serta perdebatan politik dan sosial agar tetap berada dalam kawasan konflik yang membangun. Pemilu juga harus dipandang sebagai suatu ruang konflik yang memberikan perubahan kepada masyarakat dari sebelum Pemilu sampai sesudah Pemilu. Pada akhirnya semua konflik yang terjadi pada saat Pilkada atau Pemilu dapat diselesaikan dan dicarikan jalan keluarnya. Bahwa pada konflik yang terjadi saat Pilkada tahun 2015 dan Persiapan Pemilu tahun 2019, regulasi konflik Pemilu sangat memiliki peranan, dimana dengan adanya regulasi konflik Pemilu, konflik yang terjadi dapat dikontrol dan diselesaikan dengan baik serta konflik tidak meningkat kearah yang lebih tinggi. Regulasi konflik Pemilu yang digunakan disini adalah dengan cara arbitrasi, dimana kedua belah pihak sepakat untuk mendapatkan keputusan akhir (yang bersifat legal) dan keputusan tersebut bersifat final dan mengikat. Dengan adanya regulasi konflik Pemilu, pihakpihak yang berkonflik dapat menerima keputusan atau sanksi yang diberikan tanpa adanya perlawanan. Karena disini atas keputusan DKPP dan keputusan Panwaslu adalah final dan mengikat, dengan arti kata bahwa keputusan tersebut merupakan keputusan akhir yang tidak bisa diganggu gugat. Walaupun KPU dan Panwaslu merupakan satu kesatuan fungsi karena sama-sama sebagai penyelenggara Pemilu, namun konflik yang terjadi diantara keduanya tetap tidak terhindarkan.

\section{E. UCAPAN TERIMA KASIH}

A rtikel ini merupakan hasil penelitian yang dilaksanakan oleh mahasiswa Magister Tata Kelola Pemilu FISIP Universitas Andalas, sebagai penerima beasiswa dari program kerjasama antara Komisi Pemilihan Umum Republik Indonesia dengan Universitas Andalas. Peneliti mengucapkan terima kasih terhadap semua pihak yang telah membantu sehingga penelitian ini dapat terlaksana dan terselesaikan dengan baik 


\section{DAFTAR PUSTAKA}

Afrizal. (2014). Metode Penelitian Kualitatif: Sebuah Upaya Mendukung Penggunaan Penelitian Kualitatif dalam Berbagai Disiplin IImu. Jakarta: PT Raja Grafindo Persada.

Ardila, Mega. (2018). Budaya Merantau Masyarakat dan Permasalahan Pendaftaran Pemilih Pada Pilkada di Sumatera Barat. Jurnal Antropologi; Isu-Isu Sosial Budaya, Volume 20, No. 2, 157163.

Bawaslu. (2018). Indeks Kerawanan Pemilu Pemilihan Kepala Daerah 2018. Jakarta

Budiardjo, Miriam. (2008). Dasar-Dasar Ilmu Politik. Jakarta:Gramedia Pustaka Utama.

Dahrendorf, Ralf. (1986). Konflik dan Konflik dalam Masyarakat Industri. Penterjemah;Ali Mandan, Jakarta:Rajawali. Terjemahan dari Class and Class Conflict in Industrial Society.

Dahrendorf, Ralf.. (2004). Teori SosiologiModern edisi keenam. Jakarta : PrenadaMedia

Darmawan, Ikhsan. (2010). Bentuk Resolusi Konflik Dalam Pilkada Kasus Pilkada Yogyakarta dan Kabupaten Jepara. Jurnal Politika, Volume 1, No. 1, 38-48.

Dunning, Thad. (2011). Fihgting and Voting: Violent Conflict and Electoral Politics. Jurnal of Conflict Resolution, Volume 55, No. 3, 327-339.

Gayatri. (2015). Konflik Kekuasaan Dalam Anggaran Pemilukada Provinsi Bali. EJurnal Akuntansi Universitas Udayana, Volume 12, No. 1, 111-142.

Humaedi, S., Kudus, I., Pancasilawan, R., \& Nulhaqim, S.A. (2018). Resolusi Konflik Pilkada di Kota Cimahi Jawa Barat. Volume 8, No. 1, 101-113.

Indriyani, Atek Lis. (2017). Resolusi Konflik Internal Antara Komisioner dengan Sekretariat KPU Provinsi Lampung dalam Pemilihan Gubernur Lampuang Tahun 2014. Universitas Lampung.

Lestari, Era Yuni. (2018). Menghindari Tindak Pidana Pemilu: Belajar Dari Konflik Pemilihan Umum Kepala Daerah dan Wakil Kepala Daerah. Seminar Nasional Hukum Universitas Negeri Semarang, Volume 4, No. 2, 212-227.

Liany, Lusi. (2016). Desain Hubungan Kelembagaan Penyelenggara Pemilihan Umum. Jurnal Cita Hukum Fakultas Syariah dan Hukum UIN Jakarta, Volume 4, No. 1,51-72.

Moleong, Lexy J. (2006). Metodologi Penelitian Kualitatif. Bandung : PT. Remaja Rosdakarya.

Narwoko, J. Dwi dan Bagong Suyanto. (2005). Sosiologi Teks Pengantar dan Terapan, Jakarta:Kencana Prenada Media Group

Palupi, Nugrahaeni Kenyo. (2015). Hubungan Kerja Antara Komisi Pemilihan Umum (KPU) dan Panitia Pengawas Pemilu (Panwaslu) Kabupaten Banjarnegara dalam Penyelenggaraan Pemilu Presiden dan Wakil Presiden Tahun 2014 Sesuai UU Nomor 42 Tahun 2008.

Pito, Adrianus dan Toni. (2013). Mengenal Teori-Teori Politik. Bandung:Nuansa Cendekia.

Pruit, Dean. G dan Rubin, Jeffry Z. (2004). Teori Konflik Sosial. Penterjemah : Helly P. Soetjipto dan Sri Mulyantini Soetjipto. Penyunting : Mohammad Khatamie. Terjemahan dari Social Conflict Escalation, Statemate and Settlement.

Purnamasari, Kahfi. Ashabul dan Rachman. Arief Fatchur (2015). Peran Penyelenggara Pemilu Dalam Pemilihan Legislatif 2014 di Kabupaten Siduarjo. Jurnal JKMP, Volume 3, No. 1, 1-116.

Setiadi, Elly. M dan Kolip, Usman. (2011). Pengantar Sosiologi. Jakarta : Kencana.

Siswanto, Edhi. (2017). Konflik Pemilihan Kepala Daerah Kabupaten Jember Tahun 2015. Jurnal Politico, Volume 17, No. 2, 286-312.

Sukri. (2016).Keniscayaan Konflik Dalam Masyarakat Demokrasi. Jurnal Politik Profetik, Volume 4, No. 2, 152-171.

Susan, Novri. (2009). Sosiologi Konflik dan Isu-Isu Konflik Kontemporer. Jakarta:Kencana

Surbakti, Ramlan dan Fitrianto, Hari. (2015). Transformasi Bawaslu dan Partisipasi Masyarakat Dalam Pengawasan Pemilu. Jakarta:Kemitraan Bagi Pembaharuan Tata Pemerintahan.

Surbakti, Ramlan dan Nugroho, Kris. (2015). Studi Tentang Desain Kelembagaan Pemilu Yang Efektif. Jakarta:Kemitraan Bagi Pembaharuan Tata Pemerintahan.

Ubbe, Ahmad. (2011). Laporan Pengkajian Hukum Tentang Mekanisme Penanganan Konflik Sosial. Jakarta.

Usman. (2018). Pilkada dan Conflicy Horizontal (Telaah Atas Pemilukada di Kota Makasar). Jurnal Hukum Pidana dan Ketatanegaraan, Volume 7, No. 2, 325-346.

UNDP. (2009). Election An Conflict revention A Guide To Analysis,Planning And Programming.

Winardi (2010). Menyoal Independensi dan Profesionalitas Komisi Pemilihan Umum Daerah Dalam Penyelenggaran Pemilu Kepala Daerah. Jurnal Konstitusi, Volume 3, No. 2, 51-84. 